\title{
Basophil Activation Antigens: Molecular Mechanisms and Clinical Implications
}

\author{
Peter Valent*
}

Department of Internal Medicine I, Division of Hematology and Hemostaseology, Medical University of Vienna \& Ludwig Boltzmann Cluster Oncology Vienna, Austria

\begin{abstract}
Basophil activation is a key finding in allergic reactions and also observed quite frequently in infectious diseases and autoimmune disorders. In allergic reactions, basophil-derived mediators such as histamine, contribute essentially to clinical symptoms. During IgE-dependent degranulation of basophils, a number of cell surface membrane and cytoplasmic molecules become activated, show altered expression, or are translocated into the cell surface. Although little is known so far about the exact role of these activation-linked cell surface antigens, several of them are employed as diagnostic parameters in allergic disorders. Other molecules are involved in the process of signalling and the consecutive release of pro-allergic mediators, and have therefore been proposed as potential targets of therapy. The current article provides a summary on activation-linked cell surface and cytoplasmic antigens in basophils, with special reference to potential mechanisms underlying re-translocation or over-expression in activated cells, relevant signalling pathways, and clinical implications.
\end{abstract}

This study was supported by: Fonds zur Förderung der Wissenschaftlichen Forschung in Österreich, SFB grant \# 018-20.

Key Words: Basophils, surface antigens, IgE-receptor, IL-3, IL-33, CD63, CD203c.

\section{INTRODUCTION}

Blood basophils are unique effector cells of the immune system. These cells contribute essentially to allergic and inflammatory reactions [1-4]. Unlike mast cells, basophils are circulating cells and originate from granulocytic progenitors [5-7]. Basophils also differ from mast cells in cytokine receptor expression, response to various interleukins (ILs) and tissue hormones, and expression of chymotryptic enzymes and proteoglycans (Table 1) [8-12]. Nevertheless, basophils and mast cells share several important features, including expression of the $\mathrm{IgE}$ receptor, production and storage of histamine and other proinflammatory mediators, and expression of certain cell surface antigens including CD9, CD33, CD45, and CD63 (Table 1).

In common with all other circulating leukocytes, basophils originate from immature uncommitted $\mathrm{CD} 34+$ bone marrow progenitor cells [5-7]. A number of different cytokines and other factors are involved in the regulation of growth, differentiation, and maturation of lineage-committed and multipotent basophil precursor cells. The most important growth factor for basophils appears to be IL-3 [13-15]. Other cytokines contributing to basophilopoiesis are IL-5, granulocyte macrophage colony-stimulating factor (GM-CSF), and nerve growth factor (NGF) [15-17]. These cytokines act on immature and mature basophils through specific receptors [18-20]. In fact, these regulators not only trigger differentiation and maturation of basophils but also the function of ma

*Address correspondence to this author at the Department of Internal Medicine I, Division of Hematology and Hemostaseology, Medical University of Vienna, Währinger Gürtel 18-20, A-1090 Vienna, Austria; Tel: 43140400 6085; Fax: 43140400 4030; E-mail: peter.valent@meduniwien.ac.at ture blood basophils, including survival, adhesion, chemotaxis, releasability, and cytokine production [21-27]. Mature basophils also express high affinity receptors for IgE, which play an essential role in allergic diseases [28-30]. Notably, during an allergic reaction, IgE receptors are cross-linked on basophils by an allergen via specific IgE, resulting in degranulation and mediator release, and thus in specific symptoms in allergic reactions [28-30].

During the past few decades, our knowledge on basophil activation through IgE-dependent reactions or cytokine mediation has increased considerably [28-30]. Moreover, a number of additional cell surface antigens involved in basophil activation have been identified [31-40]. The current article provides a summary of our current knowledge on cell surface activation-linked antigens on human basophils, with special focus on biochemical mechanisms underlying expression and activation of these antigens, and potential clinical implications.

\section{CELL SURFACE PHENOTYPE OF RESTING BLOOD BASOPHILS}

Resting blood basophils express a unique composition of cell surface antigens, including the high-affinity receptor for $\mathrm{IgE}$, receptors for various interleukins such as IL-3 and GMCSF, chemokine receptors, various complement receptors including CR1 (CD35) and the C5a receptor (CD88), several adhesion molecules such as beta 1 and beta 2 integrins, or ICAM-1 (CD54), and various other myeloid cell surface antigens [9-12,18-20,33,41-45] (Table 1). In common with all leukocytes, basophils display the pan leukocyte antigen CD45 and the hyaluronan receptor CD44 [9-11] (Table 1). Unlike mast cells, resting blood basophils do not express 
Table 1. Differentiation Antigens Expressed in Basophils and Mast Cells

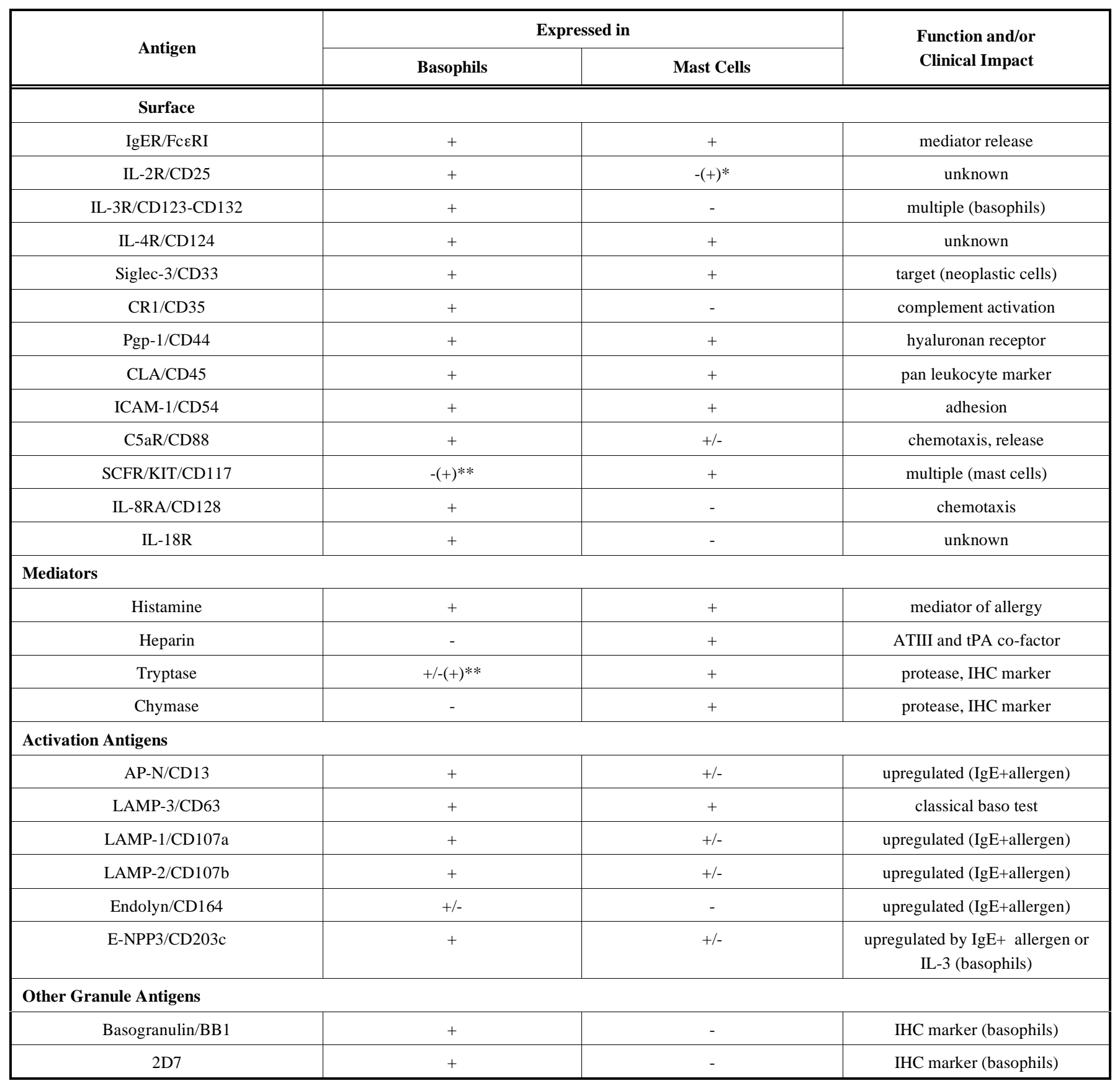

*In systemic mastocytosis, neoplastic mast cells aberrantly express CD25. **Immature basophils express low amounts of KIT and tryptase. SCF, stem cell factor; IHC, immunohistochemistry; AP-N, aminopeptidase-N.

substantial amounts of KIT (CD117) or vitronectin receptor (CD51/CD61) [9-11]. However, immature basophil progenitor cells may express low amounts of KIT, and the same may hold true for rapidly mobilized (activated) blood basophils [46-48].

A unique and rather specific marker for basophils and their progenitor cells is the ecto-enzyme ectonucleotide pyrophosphatase/phosphodiesterases 3 (ENPP-3) clustered as CD203c [33,37-40]. In fact, CD203c is expressed on immature basophil-committed CD34+ progenitor cells, immature bone marrow basophils, and mature blood basophils [33]. As will be discussed below, CD203c is also an activation-linked cell surface antigen on human basophils. Other blood leukocytes do not express substantial amounts of CD203c. However, tissue mast cells express low levels of CD203c, and when activated or transformed (neoplastic mast cells), the levels of CD203c on mast cells increase substantially [49]. Other cell surface antigens that have been described as activation-linked markers and are detectable on resting blood basophils include aminopeptidase N (CD13), the lysosomal membrane antigens LAMP-1 (CD107a), LAMP-2 (CD107b), and LAMP-3 (CD63), and endolyn (CD164) [3740,50-53]. Most of these antigens are not only detectable on 

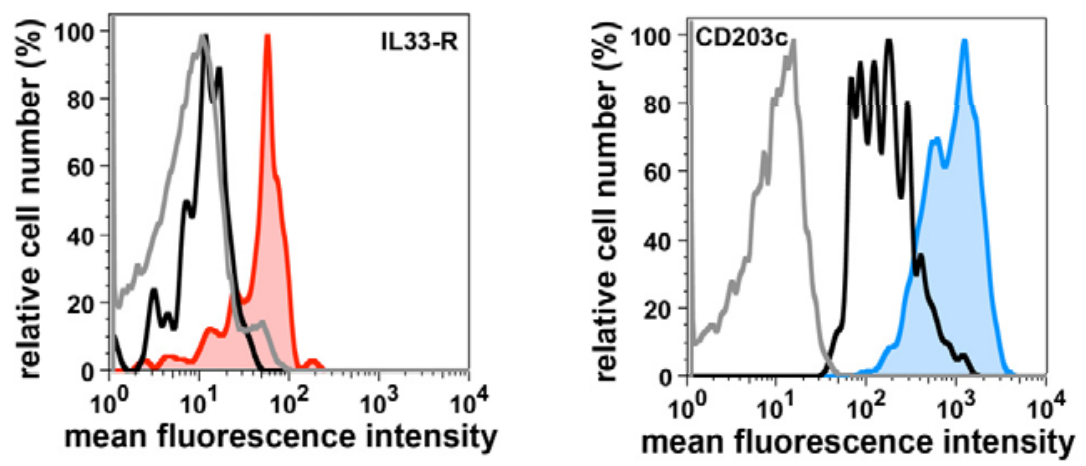

Fig. (1). Effects of IL-3 on expression of IL33-R and CD203c on human basophils.

Peripheral blood basophils obtained from a healthy donor (left panel) and from a patient with chronic myeloid leukemia (right panel) were incubated with control medium (black line, open histogram) or recombinant interleukin-3, IL-3 (100 ng/ml) (grey histogram) at $37^{\circ} \mathrm{C}$ for 15 minutes. Then, basophils were stained with an antibody against the IL-33 receptor ST2 and an antibody against CD203c, and were analyzed by multicolor flow cytometry. Incubation with IL-3 resulted in an enhanced (de novo) expression of the IL-33R (ST2) in normal basophils (left panel) and CML basophils (not shown), and in an enhanced expression of CD203c on normal basophils (not shown) and CML basophils (right panel). The grey line (open histogram) shows the isotype-matched control antibody.

the surface of basophils but also in cytoplasmic (lysosomal) membranes within basophils.

\section{CONSEQUENCES OF IgE RECEPTOR CROSS- LINKING}

During IgE receptor cross-linking, a number of signal transduction events and biochemical processes are initiated that lead to basophil activation and consecutive degranulation $[2,8,10,28,29]$. Signalling molecules that are involved in IgE receptor activation and downstream signalling cascades in basophils (and mast cells) include (among others) Fyn, Syk, and Lyn, the PI3-kinase, Akt, and phospholipase C, Ras, Raf and the MAP kinases, as well as Src, Btk, Jnk, and PKC [2,8,10,28-30,54-57]. In addition, Jak2 and Stat5 activation may be initiated after IgE receptor cross-linking in basophils [54-57]. Most of these signalling pathways are interconnected and are considered to act together to lead to basophil activation with consecutive degranulation and mediator release as well as cytokine production, cytokine release, and generation of lipid mediators in basophils [2,8,10,28-30,54-57]. Moreover, upon IgE-receptor cross linking in basophils, a number of cell surface membrane antigens appear to be translocated from cytoplasmic (lysosomal) membranes onto the cell surface [37-40,50-53]. These upregulated cell surface membrane molecules include (among others) CD11b, CD13, CD63, CD107a, CD107b, and CD203c. IgE-mediated upregulation of these antigens may depend on distinct signalling pathways including the PI3 kinase/Akt pathway [39,40,50,58].

\section{EFFECTS OF INTERLEUKIN-3 AND OTHER IN- TERLEUKINS}

Interleukin-3 (IL-3) not only promotes the differentiation and survival of human basophils but also releasability, adhesion, migration, cytokine production, and surface receptor expression [15,18-24,59-61]. In allergic patients, IL-3 may even induce mediator secretion in the absence of other agonists (i.e. allergens) [22]. An important aspect is that IL-3 markedly triggers the expression of other cell surface antigens on human basophils. Such upregulated antigens include CD203c and the receptor for IL-33 (ST2) $[62,63]$. The no- tion that IL-3 promotes the expression of CD203c has to be taken into account when using CD203c as a basophil activation marker in allergic reactions [40,64]. An interesting aspect is that ST2 (IL-33 receptor) is not detectable on resting normal basophils by conventional flow cytometry but is detectable on IL-3-exposed (primed) basophils (Fig. 1). In line with this observation, IL-33 synergizes with IL-3 in promoting basophil activation and mediator secretion [63]. Similar to IL-3, IL-5 and GM-CSF can also activate human blood basophils and promote their releasability [15,19,23-25]. In addition, the receptors for IL-3, IL-5, and GM-CSF on basophils share a common signal-transducing beta-chain $[19,20]$. However, despite expression of a common signalling receptor-chain, not all effects of IL-3 on basophils are mimicked by IL-5 and GM-CSF, or are less pronounced upon exposure to GM-CSF or IL-5 compared to effects seen with IL-3. Other cytokines and interleukins such as nerve growth factor (NGF) or IL-33 also trigger the activation of resting human blood basophils $[17,63]$. However, again, the effects of these cytokines usually are less pronounced compared to effects provoked by IL-3 [65]. All in all, IL-3 appears to be a most effective cytokine-agonist for human blood basophils.

Following cytokine exposure, a complex network of signal transduction molecules and pathways are activated in basophils. Key signalling molecules contributing to basophil activation after exposure to IL-3 are similar or the same compared to that involved in $\operatorname{IgE}$ receptor downstream signalling, and include the PI3-kinase/Akt/mTOR pathway, the MEK/ERK pathway, and the JAK/STAT pathway. An interesting aspect is that signalling through the IL-3 receptor and IgE receptor share many similarities [66,67]. Moreoever, it has been reported that the FcR gamma-chain, which can serve as component of the IL-3 receptor, is required for IL-3induced production of IL-4 in mouse basophils [45]. Whether this holds also true for human blood basophils remains at present unknown.

Recently, the effects of various novel cytokines on signal transduction in human basophils have been explored and compared to IgE-dependent and IL-3-induced activation. Interestingly, the signalling pathways triggered by IL-33 in 
blood basophils are different from that triggered by IL-3. Whereas IL-3 primarily activates the JAK/STAT pathway and ERK-activation in human basophils, IL-33 was found to activate the NFkB and p38 MAP-kinase pathway [63]. In line with this observation, IL-33 did not mimic all effects of IL-3 on human basophils. Likewise, in contrat to IL-3, IL-33 did not prime human basophils for C5a-induced LTC4 generation [63]. Furthermore, unlike IL-3, IL-33 does not promote the expression of CD203c or other surface molecules in human basophils (unpublished observation). This is of interest as IL-33 has been described to trigger releasability in human basophils $[63,68,69]$. All these observations suggest that translocation of membrane antigens onto the cell surface is not invariably linked to (not sufficient for) mediator secretion in basophils.

\section{EFFECTS OF OTHER NATURAL LIGANDS}

Apart from IL-3 and other interleukins, a number of additional natural ligands can promote basophil activation. Among these natural regulators are the interferons, the complement products $\mathrm{C} 5 \mathrm{a}$ and $\mathrm{C} 3 \mathrm{a}$, and various chemokines such as MCP-1 or IL-8 [2,3,23-25,41-44,70-77]. Whereas interferon-alpha and interferon-gamma promote basophil releasability after exposure for 12-24 hours (presumably via effects mediated by accessory cells) [70,71], C5a and the chemokines rapidly induce mediator secretion as well as chemotaxis in basophils $[41,44,72,73]$. There are a number of other effects these natural ligands have on basophils, including the regulation of cytokine production and release, survival, and adhesion [75-77]. Together, a number of different cytokines and chemokines regulate basophil function relevant to allergic or other inflammatory reactions. It is assumed that these ligands act together to trigger basophil activation. Moreover, a number of additional intrinsic and extrinsic factors, including the underlying disease, genetic background, micro-environment, presence and type of microbes, and drug intake may play a role and may determine releasability in human blood basophils [78-81].

\section{BASOPHIL ACTIVATION ASSAYS}

A number of different assays for measuring basophil activation have been proposed in the past. The first robust assay based on IgE-dependent upregulation of a cell surface antigen on basophils was the CD63-test, also known as basophil-activation-test or 'baso-test' [31,32,34,52,53,82,83]. Although exhibiting several limitations, the assay is employed as a standard in various centers. One limitation is that CD63 is not specific for basophils and is a less sensitive activation parameter. An alternative assay that exhibits high sensitivity and specificity is based on IgE-dependent upregulation of CD203c [36-40,64,84,85]. The advantage of this assay is that CD203c is specific for blood basophils (not found on other blood leukocytes) and that CD203c is a sensitive activation parameter [36-40]. On the other hand, CD63 may be more specific for allergic (IgE-dependent) reactions and may be less susceptible to non-specific upregulation by cytokines or other factors [36-39,62]. However, CD63 is not specific for basophils and may sometimes show false negative results because of its relatively low sensitivity. As a consequence, we recommend that basophil activation is measured by employing both CD63 and CD203c in a combined approach by multi-color flow cytometry $[38,64]$. An- other important aspect is that not only the percentage of reactive basophils should be counted, but also the mean fluorescence intensity (MFI) [38,64]. In fact, using a standardized approach measuring the MFI of the test marker against the MFI of the isotype control should yield reliable and reproducible results for allergen-induced basophil activation $[38,64]$. Finally, it is important to select the optimal set and type of allergen(s) to explore the allergic status at the effector cell level. Today, the use of recombinant allergens is recommended in basophil activation assays whenever possible [38,64].

\section{SIGNALLING AND EFFECTOR MOLECULES AS POTENTIAL TARGETS OF THERAPY}

A number of signalling molecules and downstream effector molecules are critical to basophil activation and the consecutive release of pro-inflammatory mediator substances [2,8,10,28-30,54-57]. Several of these signalling molecules have recently been discussed as potential targets of therapy in allergic disorders [86-90]. A list of potential targets and some targeted drugs are shown in Table 2 . In fact, there are a number of targeted drugs recognizing critical kinases and other targeted drugs used in clinical trials to treat cancer patients or patients with severe autoimmune disorders [91-96]. However, most of these drugs also have significant side effects, especially when multiple targets are identified [91-96]. Notably, most signal transduction inhibitors are not specific drugs, but are broadly acting drugs recognizing a number of different target kinases in various effector cells [97-99]. As a result, most kinase-targeting drugs cannot be used in patients with allergic disorders. Good examples for multi-kinase inhibitors that are applied in cancer patients and block IgEdependent histamine release by interfering with signal transduction pathways in basophils are dasatinib and midostaurin (PKC412) [100,101]. Many more kinase blockers are available and applied in cancer patients, but their effects on basophils or mast cells have not been investigated yet. More specific kinase inhibitors have also been developed, and some of them show inhibitory effects on basophil activation [102111]. Several of these inhibitors interact with and block Syk, suggesting that this kinase may play a particular role as potential drug target in basophils. Several of the above targets may also be involved on the translocation of activationlinked cell surface antigens (including CD63 and CD203c) on basophils. Indeed, basophils may be less capable of upregulating activation-linked cell surface antigens and to release proinflammatory mediators during treatment with multikinase inhibitors [112]. Whether such drug effects on IgE-mediated upregulation of CD antigens can be employed to monitor drug effects (on basophils) in these patients remains at present unkown.

\section{CONCLUDING REMARKS AND FUTURE PERSPEC- TIVES}

Activation-linked cell surface membrane antigens on basophils are increasingly used in research and in practice, in order to explore the biology of basophils, their role in various pathologic reactions, and to determine their responses to allergens in allergic disorders. Moreover, basophil activation antigens are increasingly employed to screen for drug effects and to determine disease activity and responses to immunotherapy and other drugs in patients with allergic diseases. 
Table 2. Examples for Kinase-Targeting Drugs and their Effects on Basophils

\begin{tabular}{|c|c|c|}
\hline PKC412 (midostaurin) & PKC, KDR, KIT, FLT3, .... & + \\
\hline Dasatinib & Abl, KIT, Lyn, Btk, Fyn, Src, ... & $+(-)^{*}$ \\
\hline STI571 (imatinib) & Abl, KIT, PDGFR, ... & - \\
\hline Piceatannol** & Syk, STAT5, ZAP70, ... & + \\
\hline R406 & Syk & n.k. \\
\hline R112 & Syk & n.k. \\
\hline NVP-BEZ235 & PI3-K \& mTOR & $+/-$ \\
\hline Rapamycin & mTOR & - \\
\hline Cyclosporin-A & Calcineurin & + \\
\hline FK506 & FK-BP & + \\
\hline
\end{tabular}

mTOR, mammalian target of rapamycin; n.k., not known; FK-BP, FK506-binding protein. *At low dose, dasatinib sometimes even promotes IgE-dependent histamine release in basophils, whereas at higher concentrations (>100 nM), dasatinib completely blocks IgE-dependent histamine release in all donors [100]. **Piceatannol is an experimental compound but not used in clinical trials.

During the past few years basophil activation antigens have been linked to certain signalling pathways and signalling molecules relevant to degranulation and mediator release. Several of these signalling molecules may represent potential drug targets. There is hope for the future that basophil research will employ these basophil-targets and basophilactivation markers with the goal to improve diagnostic assays as well as therapy in allergic patients.

\section{ACKNOWLEDGEMENT}

This study was supported by: Fonds zur Förderung der Wissenschaftlichen Forschung in Österreich, SFB grant \# 018-20. We like to thank Viviane Winter and Harald Herrmann for excellent technical assistance.

\section{REFERENCES}

[1] Dvorak AM. Cell biology of the basophil. Int Rev Cytol 1998; 180: 87-236.

[2] Valent P, Bettelheim P. The human basophil. Crit Rev Oncol Hematol 1990; 10: 327-52.

[3] Falcone FH, Haas H, Gibbs BF. The human basophil: a new appreciation of its role in immune responses. Blood 2000; 96: 4028-38.

[4] Schroeder JT. Basophils beyond effector cells of allergic inflammation. Adv Immunol 2009; 101: 123-61.

[5] Denburg JA, Richardson M, Telizyn S, Bienenstock J. Basophil/mast cell precursors in human peripheral blood. Blood 1983; 61: 775-80.

[6] Leary AG, Ogawa M. Identification of pure and mixed basophil colonies in culture of human peripheral blood and marrow cells. Blood 1984; 64: 78-83.
[7] Arock M, Schneider E, Boissan M, et al. Differentiation of human basophils: an overview of recent advances and pending questions. J Leukoc Biol 2002; 71: 557-64.

[8] MacGlashan DW Jr, Schleimer RP, Peters SP, et al. Comparative studies of human basophils and mast cells. Fed Proc 1983; 42: 2504-9.

[9] Valent P, Ashman LK, Hinterberger W, et al. Mast cell typing: demonstration of a distinct hematopoietic cell type and evidence for immunophenotypic relationship to mononuclear phagocytes. Blood 1989; 73: 1778-85.

[10] Valent P, Bettelheim P. Cell surface structures on human basophils and mast cells: biochemical and functional characterization. Adv Immunol 1992; 52: 333-423.

[11] Agis H, Füreder W, Bankl HC, et al. Comparative immunophenotypic analysis of human mast cells, blood basophils and monocytes. Immunology 1996; 87: 535-43.

[12] Florian S, Sonneck K, Czerny M, et al. Detection of novel leukocyte differentiation antigens on basophils and mast cells by HLDA8 antibodies. Allergy 2006; 61: 1054-62.

[13] Saito H, Hatake K, Dvorak AM, et al. Selective differentiation and proliferation of hematopoietic cells induced by recombinant human interleukins. Proc Natl Acad Sci USA 1988; 85: 2288-92.

[14] Valent P, Schmidt G, Besemer J, et al. Interleukin-3 is a differentiation factor for human basophils. Blood 1989; 73: 1763-59.

[15] Valent P, Dahinden CA. Role of interleukins in the regulation of basophil development and secretion. Curr Opin Hematol 2010;17: 60-6.

[16] Denburg JA, Silver JE, Abrams JS. Interleukin-5 is a human basophilopoietin: induction of histamine content and basophilic differentiation of HL-60 cells and of peripheral blood basophileosinophil progenitors. Blood 1991; 77: 1462-8.

[17] Tsuda T, Wong D, Dolovich J, et al. Synergistic effects of nerve growth factor and granulocyte-macrophage colony-stimulating fac- 
tor on human basophilic cell differentiation. Blood 1991; 77: 9719.

[18] Valent P, Besemer J, Muhm M, et al. Interleukin 3 activates human blood basophils via high-affinity binding sites. Proc Natl Acad Sci USA 1989; 86: 5542-6.

[19] Lopez AF, Eglinton JM, Lyons AB, et al. Human interleukin-3 inhibits the binding of granulocyte-macrophage colony-stimulating factor and interleukin-5 to basophils and strongly enhances their functional activity. J Cell Physiol 1990; 145: 69-77.

[20] Lopez AF, Lyons AB, Eglinton JM, et al. Specific binding of human interleukin-3 and granulocyte-macrophage colony-stimulating factor to human basophils. J Allergy Clin Immunol 1990; 85: 99102 .

[21] Dahinden CA, Kurimoto Y, De Weck AL, et al. The neutrophilactivating peptide NAF/NAP-1 induces histamine and leukotriene release by interleukin 3-primed basophils. J Exp Med 1989; 170: 1787-92.

[22] Haak-Frendscho M, Arai N, Arai K, et al. Human recombinant granulocyte-macrophage colony-stimulating factor and interleukin 3 cause basophil histamine release. J Clin Invest 1988; 82: 17-20.

[23] Hirai K, Morita Y, Misaki Y, et al. Modulation of human basophil histamine release by hemopoietic growth factors. J Immunol 1988; 141: 3958-64.

[24] Bischoff SC, de Weck AL, Dahinden CA. Interleukin 3 and granulocyte / macrophage-colony-stimulating factor render human basophils responsive to low concentrations of complement component C3a. Proc Natl Acad Sci USA 1990; 87: 6813-7.

[25] Bischoff SC, Brunner T, De Weck AL, Dahinden CA. Interleukin 5 modifies histamine release and leukotriene generation by human basophils in response to diverse agonists. J Exp Med 1990; 172: 1577-82.

[26] Kurimoto Y, De Weck AL, Dahinden CA. The effect of interleukin 3 upon IgE-dependent and IgE-independent basophil degranulation and leukotriene generation. Eur J Immunol 1991; 21: 361-8.

[27] Schroeder JT, Chichester KL, Bieneman AP. Human basophils secrete IL-3: evidence of autocrine priming for phenotypic and functional responses in allergic disease. J Immunol 2009; 182: 2432-8.

[28] Nadler MJ, Matthews SA, Turner H, Kinet JP. Signal transduction by the high-affinity immunoglobulin $\mathrm{E}$ receptor $\mathrm{Fc}$ epsilon RI: coupling form to function. Adv Immunol 2000; 76: 325-55.

[29] MacGlashan D. IgE receptor and signal transduction in mast cells and basophils. Curr Opin Immunol 2008; 20: 717-23.

[30] MacGlashan DW Jr. Self-termination/anergic mechanisms in human basophils and mast cells. Int Arch Allergy Immunol 2009; 150: 109-21.

[31] Knol EF, Mul FP, Jansen H, Calafat J, Roos D. Monitoring human basophil activation via CD63 monoclonal antibody 435. J Allergy Clin Immunol 1991; 88: 328-38.

[32] Gane P, Pecquet C, Crespeau H, Lambin P, Leynadier F, Rouger P. Flow cytometric monitoring of allergen induced basophil activation. Cytometry 1995; 19: 361-5.

[33] Bühring HJ, Simmons PJ, Pudney M, et al. The monoclonal antibody 97A6 defines a novel surface antigen expressed on human basophils and their multipotent and unipotent progenitors. Blood 1999; 94: 2343-56.

[34] Pâris-Köhler A, Demoly P, Persi L, Lebel B, Bousquet J, Arnoux B. In vitro diagnosis of cypress pollen allergy by using cytofluorimetric analysis of basophils (Basotest). J Allergy Clin Immunol 2000; 105: 339-45.

[35] Bochner BS. Systemic activation of basophils and eosinophils: markers and consequences. J Allergy Clin Immunol 2000; 106: 292-302.

[36] Valent P, Schernthaner GH, Sperr WR, et al. Variable expression of activation-linked surface antigens on human mast cells in health and disease. Immunol Rev 2001; 179: 74-81.

[37] Bühring HJ, Seiffert M, Giesert C, et al. The basophil activation marker defined by antibody 97A6 is identical to the ectonucleotide pyrophosphatase / phosphodiesterase 3. Blood 2001; 97: 3303-5.

[38] Hauswirth AW, Natter S, Ghannadan M, et al. Recombinant allergens promote expression of CD203c on basophils in sensitized individuals. J Allergy Clin Immunol 2002; 110: 102-9.

[39] Platz I, Binder M, Marxer A, Lischka G, Valent P, Bühring HJ. Hymenoptera-venom-induced upregulation of the basophil activation marker ecto-nucleotide pyrophosphatase/phosphodiesterase 3 in sensitized individuals. Int Arch Allergy Immunol 2001; 126: $335-42$.

[40] Bühring HJ, Streble A, Valent P. The basophil-specific ectoenzyme E-NPP3 (CD203c) as a marker for cell activation and allergy diagnosis. Int Arch Allergy Immunol 2004; 133: 317-29.

[41] Krieger M, Brunner T, Bischoff SC, et al. Activation of human basophils through the IL-8 receptor. J Immunol 1992; 149: 2662-7.

[42] Forssmann U, Uguccioni M, Loetscher P, et al. Eotaxin-2, a novel $\mathrm{CC}$ chemokine that is selective for the chemokine receptor CCR3, and acts like eotaxin on human eosinophil and basophil leukocytes. J Exp Med 1997; 185: 2171-6.

[43] Bischoff SC, Krieger M, Brunner T, et al. RANTES and related chemokines activate human basophil granulocytes through different G protein-coupled receptors. Eur J Immunol 1993; 23: 761-7.

[44] Uguccioni M, Mackay CR, Ochensberger B, et al. High expression of the chemokine receptor CCR3 in human blood basophils. Role in activation by eotaxin, MCP-4, and other chemokines. J Clin Invest 1997; 100: 1137-43.

[45] Hida S, Yamasaki S, Sakamoto Y, et al. Fc receptor gamma-chain, a constitutive component of the IL-3 receptor, is required for IL-3induced IL-4 production in basophils. Nat Immunol 2009; 10: 214 22.

[46] Valent P, Besemer J, Kishi K, et al. IL-3 promotes basophilic differentiation of KU812 cells through high affinity binding sites. J Immunol 1990; 145: 1885-9.

[47] Agis H, Beil WJ, Bankl HC, et al. Mast cell-lineage versus basophil lineage involvement in myeloproliferative and myelodysplastic syndromes: diagnostic role of cell-immunophenotyping. Leuk Lymphoma 1996; 22: 187-204.

[48] Heinemann A, Sturm GJ, Ofner M, et al. Stem cell factor stimulates the chemotaxis, integrin upregulation, and survival of human basophils. J Allergy Clin Immunol 2005; 116: 820-6.

[49] Hauswirth AW, Escribano L, Prados A, et al. CD203c is overexpressed on neoplastic mast cells in systemic mastocytosis and is upregulated upon IgE receptor cross-linking. Int J Immunopathol Pharmacol 2008; 21: 797-806.

[50] Hennersdorf F, Florian S, Jakob A, et al. Identification of CD13, CD107a, and CD164 as novel basophil-activation markers and dissection of two response patterns in time kinetics of IgE-dependent upregulation. Cell Res 2005; 15: 325-35.

[51] Sonneck K, Baumgartner C, Rebuzzi L, et al. Recombinant allergens promote expression of aminopeptidase-n (CD13) on basophils in allergic patients. Int J Immunopathol Pharmacol 2008; 21: 1121.

[52] Chirumbolo S, Vella A, Ortolani R, et al. Differential response of human basophil activation markers: a multi-parameter flow cytometry approach. Clin Mol Allergy 2008; 6: 12 .

[53] Sainte-Laudy J, Ouk C. Use of lipid rafting for the analysis of human basophil activation by flow cytometry. Inflamm Res 2010 ; 59(S2): 193-5.

[54] Nadler MJ, Matthews SA, Turner H, Kinet JP. Signal transduction by the high-affinity immunoglobulin $\mathrm{E}$ receptor $\mathrm{Fc}$ epsilon RI: coupling form to function. Adv Immunol 2000; 76: 325-55.

[55] Gilfillan AM, Tkaczyk C. Integrated signalling pathways for mastcell activation. Nat Rev Immunol 2006; 6: 218-30.

[56] Rivera J, Fierro NA, Olivera A, Suzuki R. New insights on mast cell activation via the high affinity receptor for IgE. Adv Immunol 2008; 98: 85-120.

[57] Gilfillan AM, Peavy RD, Metcalfe DD. Amplification mechanisms for the enhancement of antigen-mediated mast cell activation. Immunol Res 2009; 43: 15-24.

[58] Bochner BS, Sterbinsky SA. Altered surface expression of CD11 and Leu 8 during human basophil degranulation. J Immunol 1991 146: 2367-73.

[59] Bochner BS, McKelvey AA, Sterbinsky SA, et al. IL-3 augments adhesiveness for endothelium and CD11b expression in human basophils but not neutrophils. J Immunol 1990; 145: 1832-7.

[60] Yamaguchi M, Hirai K, Shoji S, et al. Haemopoietic growth factors induce human basophil migration in vitro. Clin Exp Allergy 1992; 22: $379-83$

[61] Tanimoto Y, Takahashi K, Kimura I. Effects of cytokines on human basophil chemotaxis. Clin Exp Allergy 1992; 22: 1020-5.

[62] Hauswirth AW, Sonneck K, Florian S, et al. Interleukin-3 promotes the expression of E-NPP3/CD203C on human blood basophils in healthy subjects and in patients with birch pollen allergy. Int $\mathrm{J}$ Immunopathol Pharmacol 2007; 20: 267-78. 
[63] Pecaric-Petkovic T, Didichenko SA, Kaempfer S, et al. Human basophils and eosinophils are the direct target leukocytes of the novel IL-1 family member IL-33. Blood 2009; 113: 1526-34.

[64] Valent P, Hauswirth AW, Natter S, Sperr WR, Bühring HJ, Valenta R. Assays for measuring in vitro basophil activation induced by recombinant allergens. Methods. 2004; 32: 265-70.

[65] Miura K, Saini SS, Gauvreau G, MacGlashan DW Jr. Differences in functional consequences and signal transduction induced by IL3 , IL-5, and nerve growth factor in human basophils. J Immunol 2001; 167: 2282-91

[66] Sha Q, Poulsen LK, Gerwien J, et al. Signaling transduction pathways involved in basophil adhesion and histamine release. Chin Med J 2006; 119: 122-30.

[67] Gibbs BF, Räthling A, Zillikens D, et al. Initial Fc epsilon RImediated signal strength plays a key role in regulating basophil signaling and deactivation. J Allergy Clin Immunol 2006; 118: 1060-7.

[68] Suzukawa M, Iikura M, Koketsu R, et al. An IL-1 cytokine member, IL-33, induces human basophil activation via its ST2 receptor. J Immunol 2008; 181: 5981-9.

[69] Smithgall MD, Comeau MR, Yoon BR, et al. IL-33 amplifies both Th1- and Th2-type responses through its activity on human basophils, allergen-reactive Th2 cells, iNKT and NK cells. Int Immunol 2008; 20: 1019-30.

[70] Ida S, Hooks JJ, Siraganian RP, Notkins AL. Enhancement of IgEmediated histamine release from human basophils by viruses: role of interferon. J Exp Med 1977; 145: 892-906.

[71] Hernandez-Asensio M, Hooks JJ, Ida S, Siraganian RP, Notkins $\mathrm{AL}$. Interferon-induced enhancement of IgE-mediated histamine release from human basophils requires RNA synthesis. J Immunol 1979; 122: 1601-3.

[72] Schulman ES, Post TJ, Henson PM, Giclas PC. Differential effects of the complement peptides, C5a and C5a des Arg on human basophil and lung mast cell histamine release. J Clin Invest 1988; 81: 918-23.

[73] Füreder W, Agis H, Willheim M, et al. Differential expression of complement receptors on human basophils and mast cells. Evidence for mast cell heterogeneity and CD88/C5aR expression on skin mast cells. J Immunol 1995; 155: 3152-60.

[74] Kuna P, Reddigari SR, Rucinski D, et al. Monocyte chemotactic and activating factor is a potent histamine-releasing factor for human basophils. J Exp Med 1992; 175: 489-93.

[75] Dahinden CA, Krieger M, Brunner T, Bischoff SC. Basophil activation by members of the chemokine superfamily. Adv Exp Med Biol 1993; 351: 99-110.

[76] Kaplan AP, Kuna P, Reddigari SR. Chemokines as allergic mediators--relationship to histamine-releasing factors. Allergy 1994; 49: 495-501.

[77] Dahinden CA, Geiser T, Brunner T, et al. Monocyte chemotactic protein 3 is a most effective basophil- and eosinophil-activating chemokine. J Exp Med 1994; 179: 751-6.

[78] Marone G, Spadaro G, Patella V, Genovese A. The clinical relevance of basophil releasability. J Allergy Clin Immunol 1994; 94 : 1293-1303.

[79] MacGlashan DW. Relationship between spleen tyrosine kinase and phosphatidylinositol 5' phosphatase expression and secretion from human basophils in the general population. J Allergy Clin Immunol 2007; 119: 626-33.

[80] Youssef LA, Schuyler M, Gilmartin L, et al. Histamine release from the basophils of control and asthmatic subjects and a comparison of gene expression between "releaser" and "nonreleaser" basophils. J Immunol 2007; 178: 4584-94.

[81] Lourenço FD, Azor MH, Santos JC, et al. Activated status of basophils in chronic urticaria leads to interleukin-3 hyperresponsiveness and enhancement of histamine release induced by anti-IgE stimulus. Br J Dermatol 2008; 158: 979-86.

[82] Sainte-Laudy J, Sabbah A, Drouet M, Lauret MG, Loiry M. Diagnosis of venom allergy by flow cytometry. Correlation with clinical history, skin tests, specific IgE, histamine and leukotriene C4 release. Clin Exp Allergy 2000; 30: 1166-71.

[83] Sanz ML, Sánchez G, Gamboa PM, et al. Allergen-induced basophil activation: CD63 cell expression detected by flow cytometry in patients allergic to Dermatophagoides pteronyssinus and Lolium perenne. Clin Exp Allergy 2001; 31: 1007-13.
[84] de Weck AL, Sanz ML, Gamboa PM, et al. Diagnostic tests based on human basophils: more potentials and perspectives than pitfalls. Int Arch Allergy Immunol 2008; 146: 177-89.

[85] Hausmann OV, Gentinetta T, Bridts CH, Ebo DG. The basophil activation test in immediate-type drug allergy. Immunol Allergy Clin North Am 2009; 29: 555-66.

[86] Colgan J, Rothman P. Manipulation of signaling to control allergic inflammation. Curr Opin Allergy Clin Immunol 2007; 7: 51-6.

[87] Lusková P, Dráber P. Modulation of the Fcepsilon receptor I signaling by tyrosine kinase inhibitors: search for therapeutic targets of inflammatory and allergy diseases. Curr Pharm Des 2004; 10: 1727-37.

[88] Kovarova M, Rivera J. A molecular understanding of mast cell activation and the promise of anti-allergic therapeutics. Curr Med Chem 2004; 11: 2083-91.

[89] Saxon A, Zhu D, Zhang K, Chan LA, Kepley CL. Recent advances in the use of genetically engineered negative signaling molecules to treat allergic diseases. Arb Paul Ehrlich Inst Bundesamt Sera Impfstoffe Frankf AM 2006; 95: 223-31.

[90] MacGlashan DW Jr. Self-termination/anergic mechanisms in human basophils and mast cells. Int Arch Allergy Immunol 2009; 150: 109-21.

[91] Arora A, Scholar EM. Role of tyrosine kinase inhibitors in cancer therapy. J Pharmacol Exp Ther 2005; 315:971-9.

[92] Quintás-Cardama A, Cortés JE, Kantarjian H. Practical management of toxicities associated with tyrosine kinase inhibitors in chronic myeloid leukemia. Clin Lymphoma Myeloma 2008; 8(S3): 82-8.

[93] Martinelli G, Iacobucci I, Papayannidis C, Soverini S. New targets for Ph+ leukaemia therapy. Best Pract Res Clin Haematol 2009; 22: 445-54.

[94] Hartmann JT, Haap M, Kopp HG, Lipp HP. Tyrosine kinase inhibitors - a review on pharmacology, metabolism and side effects. Curr Drug Metab 2009; 10: 470-81.

[95] Cheng H, Force T. Molecular mechanisms of cardiovascular toxicity of targeted cancer therapeutics. Circ Res 2010; 106: 21-34.

[96] Courtney KD, Corcoran RB, Engelman JA. The PI3K Pathway As Drug Target in Human Cancer. J Clin Oncol 2010; 28: 1075-83.

[97] Hantschel O, Rix U, Schmidt U, et al. The Btk tyrosine kinase is a major target of the Bcr-Abl inhibitor dasatinib. Proc Natl Acad Sci USA 2007; 104: 13283-8.

[98] Rix U, Hantschel O, Dürnberger G, et al. Chemical proteomic profiles of the BCR-ABL inhibitors imatinib, nilotinib, and dasatinib reveal novel kinase and nonkinase targets. Blood 2007; 110: 4055-63.

[99] Rix U, Superti-Furga G. Target profiling of small molecules by chemical proteomics. Nat Chem Biol 2009; 5: 616-24.

[100] Kneidinger M, Schmidt U, Rix U, et al. The effects of dasatinib on $\mathrm{IgE}$ receptor-dependent activation and histamine release in human basophils. Blood 2008; 111: 3097-107.

[101] Krauth MT, Mirkina I, Herrmann H, Baumgartner C, Kneidinger M, Valent P. Midostaurin (PKC412) inhibits immunoglobulin Edependent activation and mediator release in human blood basophils and mast cells. Clin Exp Allergy 2009; 39: 1711-20.

[102] de Paulis A, Cirillo R, Ciccarelli A, Condorelli M, Marone G. FK506, a potent novel inhibitor of the release of proinflammatory mediators from human Fc epsilon RI+ cells. J Immunol 1991; 146: 2374-81.

[103] Cirillo R, de Paulis A, Ciccarelli A, Triggiani M, Marone G. Ciclosporin A inhibits mediator release from human Fc epsilon RI+ cells by interacting with cyclophilin. Int Arch Allergy Appl Immunol 1991; 94: 76-7.

[104] Sperr WR, Agis H, Semper H, et al. Inhibition of allergen-induced histamine release from human basophils by cyclosporine A and FK-506. Int Arch Allergy Immunol 1997; 114: 68-73.

[105] Miura K, Lavens-Phillips S, MacGlashan DW Jr. Piceatannol is an effective inhibitor of IgE-mediated secretion from human basophils but is neither selective for this receptor nor acts on syk kinase at concentrations where mediator release inhibition occurs. Clin Exp Allergy 2001; 31: 1732-9.

[106] Marone G, Genovese A, Granata F, et al. Pharmacological modulation of human mast cells and basophils. Clin Exp Allergy 2002; 32: 1682-9.

[107] Yamamoto N, Takeshita K, Shichijo M, et al. The orally available spleen tyrosine kinase inhibitor 2-[7-(3,4-dimethoxyphenyl)imidazo[1,2-c]pyrimidin-5-ylamino]nicotinamide dihydrochloride 
(BAY 61-3606) blocks antigen-induced airway inflammation in rodents. J Pharmacol Exp Ther 2003; 306: 1174-81.

[108] Meltzer EO, Berkowitz RB, Grossbard EB. An intranasal Sykkinase inhibitor (R112) improves the symptoms of seasonal allergic rhinitis in a park environment. J Allergy Clin Immunol 2005; 115: 791-6.

[109] Braselmann S, Taylor V, Zhao H, et al. R406, an orally available spleen tyrosine kinase inhibitor blocks fc receptor signaling and reduces immune complex-mediated inflammation. J Pharmacol Exp Ther 2006; 319: 998-1008.
[110] Takano-Ohmuro H, Yoshida LS, Yuda Y, Morioka K, Kitani S. Shikonin inhibits IgE-mediated histamine release by human basophils and Syk kinase activity. Inflamm Res 2008; 57: 484-8.

[111] Masuda ES, Schmitz J. Syk inhibitors as treatment for allergic rhinitis. Pulm Pharmacol Ther 2008; 21: 461-7.

[112] Sillaber C, Herrmann H, Bennett K, et al. Immunosuppression and atypical infections in CML patients treated with dasatinib at 140 mg daily. Eur J Clin Invest 2009; 39: 1098-109.

Received: January 24, 2010

Revised: May 12, 2010

Accepted: May 14, 2010

(C) Peter Valent; Licensee Bentham Open.

This is an open access article licensed under the terms of the Creative Commons Attribution Non-Commercial License (http://creativecommons.org/licenses/by-nc/3.0/) which permits unrestricted, non-commercial use, distribution and reproduction in any medium, provided the work is properly cited. 